\title{
Increased DJ-I expression under oxidative stress and in Alzheimer's disease brains
}

\author{
Stéphanie Baulac ${ }^{1}$, Hope Lu${ }^{1}$, Jennifer Strahle ${ }^{1}$, Ting Yang1, \\ Matthew S Goldberg1,4, Jie Shen ${ }^{1}$, Michael G Schlossmacher ${ }^{1}$, \\ Cynthia A Lemere ${ }^{1}$, Qun $\mathrm{Lu}^{2,3}$ and Weiming Xia*1
}

\begin{abstract}
Address: ${ }^{1}$ Center for Neurologic Diseases, Department of Neurology, Brigham and Women's Hospital, Harvard Medical School, Harvard University, Boston, MA 02115, USA, ${ }^{2}$ Harriet and John Wooten Laboratory of Alzheimer's Disease Research, The Brody School of Medicine, East Carolina University, Greenville, NC 27834, USA, ${ }^{3}$ Department of Anatomy and Cell Biology, The Brody School of Medicine, East Carolina University, Greenville, NC 27834, USA and ${ }^{4}$ Departments of Neurology and Psychiatry, The University of Texas Southwestern Medical Center, Dallas, TX 75390-8813, USA

Email: Stéphanie Baulac - stephanie.baulac@upmc.fr; Hope Lu - hope.lu@duke.edu; Jennifer Strahle - strah012@umn.edu; Ting Yang - tyang3@partners.org; Matthew S Goldberg - matthew.goldberg@utsouthwestern.edu; Jie Shen - jshen@rics.bwh.harvard.edu; Michael G Schlossmacher - mschlossmacher@ohri.ca; Cynthia A Lemere - clemere@rics.bwh.harvard.edu; Qun Lu - luq@ecu.edu; Weiming Xia* - wxia@rics.bwh.harvard.edu

* Corresponding author
\end{abstract}

Published: 25 February 2009

Molecular Neurodegeneration 2009, 4:12 doi:10.1186/1750-1326-4-12
Received: 24 September 2008

Accepted: 25 February 2009

This article is available from: http://www.molecularneurodegeneration.com/content/4/I/I2

(c) 2009 Baulac et al; licensee BioMed Central Ltd.

This is an Open Access article distributed under the terms of the Creative Commons Attribution License (http://creativecommons.org/licenses/by/2.0), which permits unrestricted use, distribution, and reproduction in any medium, provided the original work is properly cited.

\begin{abstract}
Mutations in the DJ-I gene have been linked to autosomal recessive familial Parkinson's disease. To understand the function of $\mathrm{DJ}-\mathrm{I}$, we determined the $\mathrm{DJ}-\mathrm{I}$ expression in both zebrafish and post mortem human brains. We found that $\mathrm{DJ}-\mathrm{I}$ was expressed early during zebrafish development and throughout adulthood. Knock down (KD) of DJ-I by injection of morpholino did not cause dramatic morphologic alterations during development, and no loss of dopaminergic neurons was observed in embryos lacking DJ-I. However, DJ-I KD embryos were more susceptible to programmed cell death. While a slight reduction in staining for islet-I positive neurons was observed in both DJ-I KD and $\mathrm{H}_{2} \mathrm{O}_{2}$ treated embryos, the number of apoptotic cells was significantly increased in both $\mathrm{KD}$ and $\mathrm{H}_{2} \mathrm{O}_{2}$ treated embryos. Interestingly, DJ-I expression was increased in brains of zebrafish under conditions of oxidative stress, indicating that $D J-I$ is a part of stress-responsive machinery. Since oxidative stress is one of the major contributors to the development of Alzheimer's disease (AD), we also examined $D J$-I expression in AD brains. Using $D J-I$ specific antibodies, we failed to detect a robust staining of $D J-I$ in brain tissues from control subjects. However, DJ-I immunoreactivity was detected in hippocampal pyramidal neurons and astrocytes of $A D$ brains. Therefore, our results strongly suggest that $D J-I$ expression is not necessary during zebrafish development but can be induced in zebrafish exposed to oxidative stress and is present in human AD brains.
\end{abstract}

\section{Background}

Parkinson's disease (PD) and Alzheimer's disease (AD) are the two most common neurodegenerative disorders.
PD is characterized by loss of dopaminergic (DA) neurons in the substantia nigra and accumulation of intraneuronal inclusions known as Lewy bodies. AD is characterized by 
two major hallmarks, neurofibrillary tangles and neuritic plaques. Genetic studies of PD have demonstrated that two autosomal dominant genes ( $\alpha$-synuclein and LRRK2) [1-3] and three autosomal recessive genes (Parkin, PINK1, and DJ-1) are linked to PD [4-6]. Earlier reports indicate that DJ-1 is expressed in astrocytes and neurons in both control and PD brains, and it is not a major component of Lewy bodies, the pathological hallmark of PD [7,8]. Interestingly, DJ-1 has been reported to co-localize with Tau in neurofibrillary tangles from brains of AD patients, suggesting that PD-linked DJ-1 may play a role in $\mathrm{AD}[8,9]$. Recent studies have found that DJ-1 is enriched in brain tissue containing insoluble hyperphosphorylated tau [10]. In addition, accumulation of acidic isoforms of DJ-1 monomers [10] and basic isoforms of DJ-1 dimers [11] have been found in brains of PD and AD brains. These studies have shown that DJ-1 is subjected to cysteine and methionine oxidation, and the oxidative damage to DJ-1 could be associated with both PD and AD [11].

High levels of DJ-1 mRNA have been detected in neuronal and non-neuronal populations of several regions in mouse brain by in situ hybridization [12]. A recent study has shown that DJ-1 expression is up-regulated in neuroblastoma cells exposed to rotenone or 6-hydroxydopamine, which leads to the formation of intracellular reactive oxygen species. Treatment of the mouse hippocampal cell line HT22 with $\mathrm{H}_{2} \mathrm{O}_{2}$ significantly increases the immunoreactivity of DJ-1 [13]. This up-regulation of DJ-1 is suppressed when cells are pre-treated with antioxidant [14].

Pharmacological studies have shown that DJ-1 is needed for the protective effects of certain compounds which are known to inhibit the production of reactive oxygen species [15]. DJ-1 prevents oxidative stress-induced cell death of neuroblastomas, dopaminergic cells and primary neuronal cells in the presence of these compounds and knock down (KD) of DJ-1 eliminates the suppressive effect of these compounds [15]. Overexpression of DJ-1 was found to decrease the expression of BAX and inhibit caspase activation, while KD of DJ-1 increased BAX protein levels, caspase-3 activation and UV exposure-induced cell death. DJ1 has been found to directly interact with p53, and its sumoylated form inhibits p53 transcriptional activity $[16,17]$. DJ-1 also stabilizes antioxidant transcriptional master regulator Nrf2 [18] and is involved in the pathway that suppresses JNK1 signaling. DJ-1 was shown to directly target MEKK1 and inhibit MEKK1 kinase activity, and KD of DJ-1 or expression of a mutant L166P form rendered cells vulnerable to death upon stress-induced activation of the MEKK1-SEK1-JNK1 signaling pathway [19].

L166P in addition to E64D, M26I, A104T, and D149A is one of known mutations within DJ-1 that has been iden- tified from familial PD cases. These mutant forms of DJ-1 show different levels of structural alteration (except for E64D due to similar residue replacement), which lead to reduced stability of DJ-1 $[20,21]$. The L166P form of DJ-1 has an extremely short half life, supporting the notion that mutations in DJ-1 represent a loss-of-function mutation [21].

DJ-1 knockout (KO) mice do not differ from wild type mice with respect to morphology or dopaminergic cell loss [22-24], with no dopaminergic neuronal deficit seen even in aged DJ-1 KO mice [25]. However, isolated mitochondria from DJ-1 KO mice show a 2 fold increase in $\mathrm{H}_{2} \mathrm{O}_{2}$, and DJ-1 appeared to function as a peroxiredoxinlike peroxidase in these animals [23]. In zebrafish, DJ-1 is highly conserved [26], and KD of DJ-1 causes extensive apoptosis [27]. In Drosophila, deficiency in the functional DJ-1 orthologous genes DJ- $1 \alpha$ and DJ- $1 \beta$ (by KD and introduction of loss-of-function mutation) renders the fly vulnerable to paraquat-induced oxidative stress, motor impairment and decreased life span [28].

Zebrafish are beginning to be used for aging research, e.g., brief exposure of zebrafish embryos with Dichlorodihydrofluorescein diacetate allows repeated measurement of the level of reactive oxygen species generation in live fish [29]. For neurodegenerative diseases, both zebrafish and goldfish have been used to model the Parkinson's disease [30,31]. Loss of postural reflexes and initiation of movement have been replicated in part in zebrafish and goldfish treated by 1-methyl-4-phenyl-1,2,3,6tetrahydropyridine (MPTP), a known mitochondrial complex I toxin that has been extensively used to kill DA neurons in a variety of animal models for PD [32-34]. In zebrafish and goldfish, DA neurons are found only in forebrains. It has been proposed that some of these DA neurons in fish forebrains are functionally analogous to DA neurons in both mammalian forebrains and midbrains, especially to the mammalian midbrain ventral tegmental and substantia nigra area [35,36]. Therefore, efforts have been undertaken to generate transgenic zebrafish in which the DA-like monoaminergic neurons are labeled by green fluorescent protein, and elimination of DA-like neurons in zebrafish forebrains is expected to mimic the events implicated in human PD pathogenesis [37].

In this report, we compared KD of DJ-1 to oxidative stress in zebrafish embryos. In addition, we examined DJ-1 expression in the adult fish brain by treating live animals with $\mathrm{H}_{2} \mathrm{O}_{2}$. We found that KD of DJ-1 and $\mathrm{H}_{2} \mathrm{O}_{2}$ had similar effects on islet-1 positive neurons (islet-1 is a LIM (Lin11, Isl-1, Mec-3) homeodomain protein), with both groups of embryos showing an increased number of apoptotic cells. Since the oxidative stress is one of the major 
contributors to the AD pathogenesis $[38,39]$, we evaluated DJ-1 immunoreactivity in brain sections from AD and control cases and found a robust neuronal staining of $\mathrm{DJ}-1$ in post mortem $\mathrm{AD}$ brain tissues.

\section{Methods \\ Fish strains}

Embryos were obtained from natural spawning of wildtype (Tubingen longfin strain) adults and were raised and staged according to Kimmel et al. [40].

\section{Antisense morpholino injection}

DJ-1 MO, directed against the 5' untranslated region (UTR) of DJ-1 (GeneTools, Corvallis, OR, USA) was injected into fertilized zebrafish eggs at the one-cell stage at which time morpholinos can rapidly spread into all cells. The morpholino sequences were as follows: DJ-1 MO, 5'-GCGTCTAATAACCTGTGCGTGTCTG-3' control MO, 5'-ССТСCTACCTCAGTTACAATTTATA-3'.

The above standard control MO was synthesized against the zebrafish $\beta$-globin intron. MO oligonucleotides were dissolved in $1 \times$ Danieu solution at $5 \mathrm{mM}$, diluted to 0.1 $\mathrm{mM}$ prior to injection, and $\sim 4 \mathrm{ng}$ was injected into each embryo. After injection, embryos were incubated at $28.5^{\circ} \mathrm{C}$ in embryo medium [41] containing $0.002 \% 1$ phenyl-2 thiourea to inhibit pigment formation until they were de-chorionated, deyolked and lysed in sample buffer at 48 hours post fertilization (hpf) for western blot, or fixed overnight in $4 \%$ paraformaldehyde.

\section{TUNEL staining}

TUNEL assay was performed using the TMR-RED in situ cell death detection kit [42] according to the manufacturer's instructions. Optical sections were taken with a Zeiss LMR510 confocal Microscope.

\section{In situ hybridization and immunohistochemistry}

In situ hybridization was carried out according to standard protocols [43] using a probe against zebrafish tyrosine hydroxylase $(\mathrm{TH})$. Single-stranded RNA probes against TH from the cDNA clone in the pBluescript II KS+ vector (from Dr. Su Guo, University of California at San Francisco, CA) was synthesized using T7 RNA polymerase after linearization by restriction digest and then labeled with digoxigenin-UTP (Roche, Basel, Switzerland). For immunohistochemistry, standard protocols were followed using $1 \%$ Triton X-100 in phosphate-buffered saline to permeabilize the embryos and Vector VIP peroxidase substrate kit for the colorimetric reaction (Vector Laboratories, Burlingame, CA, USA). Over one dozen embryos were examined for each experiment. The antibody 39.4D5 against islet- 1 was obtained from the Developmental Studies Hybridoma Bank maintained by The University of Iowa.
Human postmortem cortical tissue was collected in accordance with Institutional Review Board-approved guidelines at Brigham and Women's hospital. Blocks of cortex were fixed for $\sim 2$ hrs in $10 \%$ neutral buffered formalin, as previously described [44]. Paraffin-embedded 8 $\mu \mathrm{m}$ serial sections were blocked for $1 \mathrm{hr}$ in $10 \%$ goat serum (for polyclonal DJ-1-N), 10\% rabbit serum (for polyclonal Park7), or 10\% horse serum (for monoclonal KAM-SA100 or E2.19) and incubated overnight at $4{ }^{\circ} \mathrm{C}$ with primary antibodies DJ-1-N (1:50), Park7 (1:100, against C-terminus of DJ-1, from Abcam), KAM-SA100 (1:100, against full length DJ-1, from Stressgen), E2.19 (1:100, against full length DJ-1, from Dr. Y. Hod and Abcam)[45]. For preabsorption, $5 \mu \mathrm{g}$ of DJ-1 peptide per $\mu \mathrm{l}$ of DJ-1 serum was used. For double immunofluorescence, rabbit polyclonal anti-GFAP (1:500, Dako) and DJ$1-\mathrm{N}(1: 50)$ were used.

\section{Western blotting}

Human, mouse and zebrafish brain samples were homogenized in lysis buffer containing $0.2 \%$ NP-40. The lysates were collected after $1 \mathrm{hr}$ of centrifugation at $100000 \times \mathrm{g}$ (human and mouse) or after 5 min of centrifuge at 18,000 $\times \mathrm{g}$ (zebrafish). Individual de-chorionated and de-yolked embryos were lysed, and all samples were heated in $1 \times$ sample buffer (3\% sodium dodecyl sulfate, 3\% $\beta$-mercaptoethanol, 15\% glycerol, and bromophenol blue) and then separated by sodium dodecyl sulfate polyacrylamide gel electrophoresis. Antibodies KAM-SA100 (1:1000, Stressgen) and anti-DJ-1-N (1:500) and an enhanced chemiluminescence system (Amersham, Piscataway, NJ, USA) were used to detect the western blots.

\section{Exposure of $A \beta$ in cultured cells}

Wildtype CHO cells and APP stably transfected CHO cells (CHO+APP) were grown for $24 \mathrm{hrs}$ before the conditioned media were collected for the measurement of $A \beta$ levels by ELISA, as previously described [46]. The same conditioned media were applied to PC-12 cells for $24 \mathrm{hr}$, and cells were collected for the quantification of DJ-1 by Western blot using antibody DJ-1-N.

\section{Results \\ Detection of human and zebrafish DJ-I}

We generated an affinity purified polyclonal antibody DJ$1-\mathrm{N}$ against the $\mathrm{N}$-terminus of DJ-1 that recognizes a single band at $23 \mathrm{kDa}$ corresponding to endogenous DJ-1 from human cortex homogenate; this band was absent when the antibody was preabsorbed with its cognate peptide (Fig. 1A). The same band was recognized by a commercially available monoclonal antibody (KAM-SA100) raised against full-length human recombinant DJ-1 (Fig. 1A). We further tested the specificity of this antibody by Western blotting of brain homogenate from a wild type or DJ-1 knockout mouse. Using the antibody DJ-1-N we 
A.

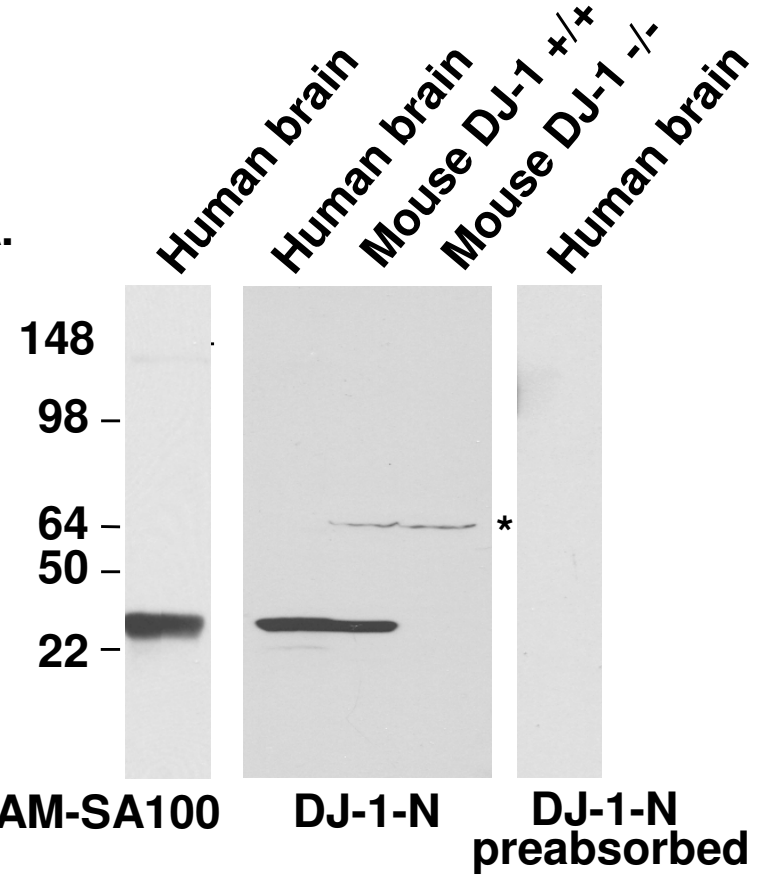

B.

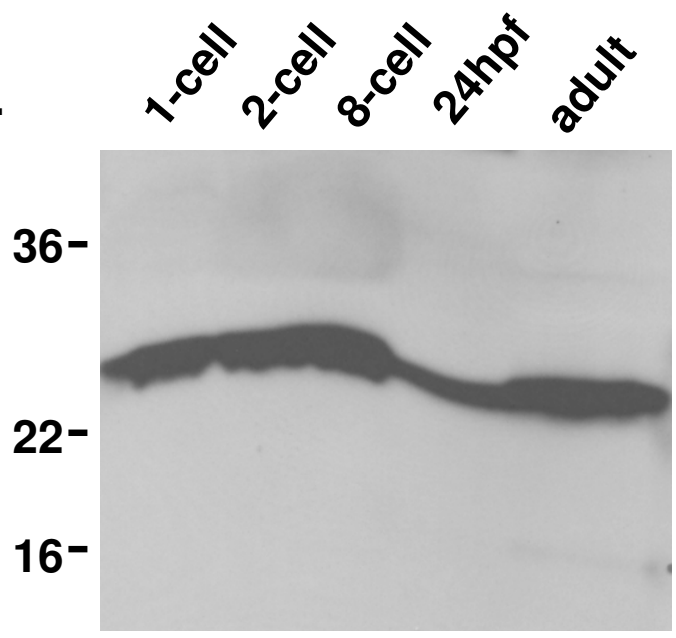

C.

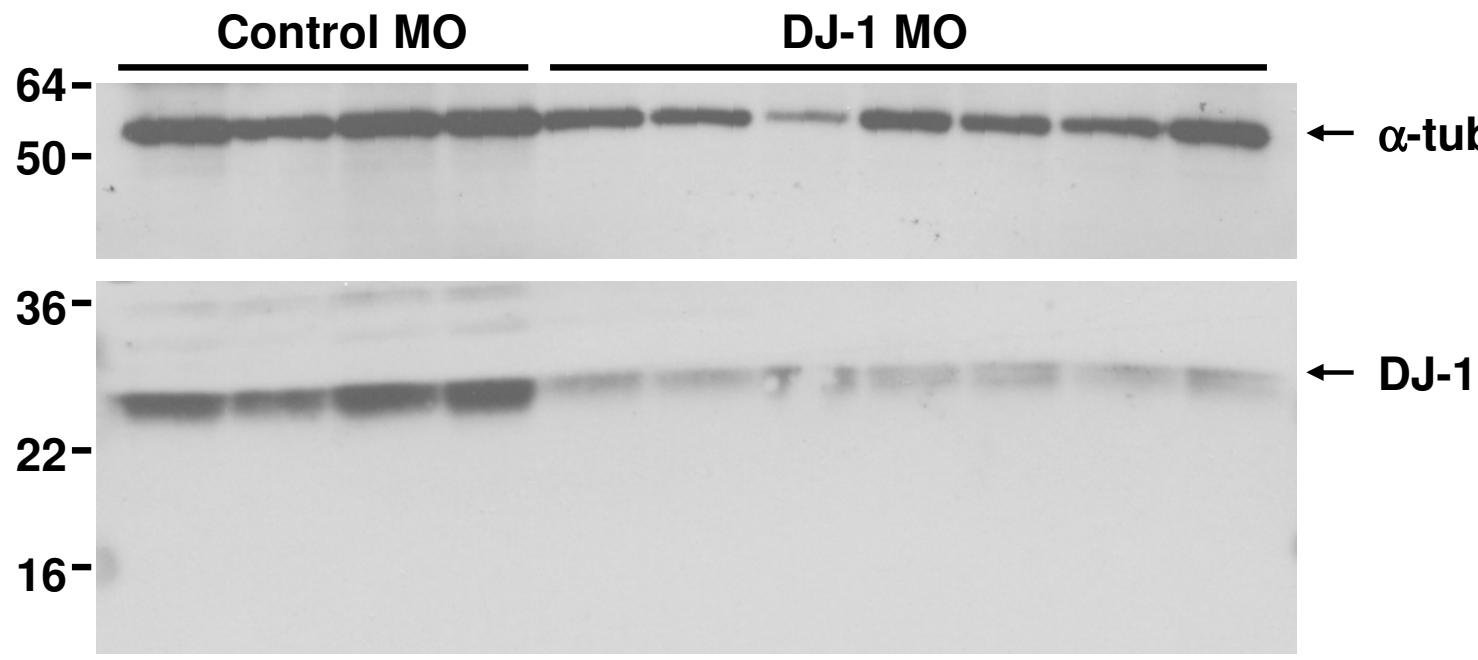

Figure I

Knockdown of DJ-I in zebrafish embryos. A. Abundant $D J-I$ expression in human brain lysate from a control case, as detected by Western Blot (WB) with KAM-SAI00 and anti-DJ-I-N antibodies, but not when anti-DJ-I-N was pre-absorbed with the synthetic DJ-I peptide. Specificity of anti-DJ-I-N antibody was confirmed by detecting $D J-I$ in wild type mouse brain lysate but not in the DJ-I knockout mouse brain lysate. A minor cross-reacting band at $\sim 70 \mathrm{kDa}$ was detected in extracts of both wild type and DJ-I knockout mouse brain, but not in human brain extracts. B. Zebrafish embryos at different developmental stages and brains of adult zebrafish were lysed for Western blotting with antibody E2.19. High levels of DJ-I protein were found in embryos at all developmental stages and in adult brains. C. Extracts taken from individual embryos at $24 \mathrm{hpf}$ were run on WB with antibody E2.19 (bottom panel). The same blot was re-probed with antibody against $\alpha$-tubulin (top panel). DJ-I protein levels were dramatically reduced in DJ-I KD embryos compared to control embryos.

detected the corresponding $23 \mathrm{kDa}$ band in wild type but not DJ-1 knockout mouse brain lysates (Fig. 1A). We then prepared zebrafish embryos at different developmental stages as well as brain lysates from adult zebrafish for
Western blotting using another commercially available monoclonal antibody E2.19 (Fig. 1B). Staining of zebrafish lysates with DJ-1-N showed the same results (data not shown). We found that DJ-1 was expressed early 
in embryonic development and persisted into adulthood (Fig. 1B).

\section{Knockdown of $D J-I$ in zebrafish embryos}

Using the human DJ-1 sequence, we identified multiple zebrafish ESTs and obtained the complete zebrafish DJ-1 sequence by the alignment of these ESTs with genomic zebrafish DJ-1 sequences from the Sanger Institute. We only found one DJ-1 homologue in zebrafish. Zebrafish DJ-1 has 4 exons that encode 189 amino acids, and the protein is $87 \%$ homologous to human DJ- 1 . cDNA from zebrafish embryos at the 1-somite stage was prepared and the full-length zebrafish DJ-1 cloned. The sequence of cDNA was confirmed and found to be identical to the one previously reported [27].

A morphant technology that uses morpholino phosphodiamidate anti-sense oligonucleotides (morpholinos, $\mathrm{MO}$ ) to target genes in vivo [47-49] was used to knock down DJ-1. We used a stock concentration of $0.5 \mathrm{mM} \mathrm{MO}$ targeting DJ-1 and injected DJ-1 MO into embryos at the 1-cell stage. In all experiments, DJ-1 MO injected embryos were compared to embryos injected with a standard control $\mathrm{MO}$ targeting the $\beta$-globin intron. To confirm the reduction of DJ-1 protein, we examined protein extracts from these embryos at 48 hours post fertilization (hpf) on Western blots (Fig. 1C). DJ-1 was similarly reduced in individual embryos injected with DJ-1 MO compared to control MO injected embryos. The same blot was probed with antibody against $\alpha$-tubulin as a loading control. Since we transiently knocked down DJ-1 expression, it was different from DJ-1 null animal, as we failed to see a lasting effect of DJ-1 morpholino at $72 \mathrm{hpf}$ (data not shown). In contrast to DJ-1 null mouse which was used for our antibody characterization (Fig. 1A), a lack of DJ-1 null zebrafish prevents us from analyzing animals at later development and adult stages. However, although DJ-1 MO did not completely eliminate DJ-1, the reduction of DJ-1 protein was prominent and consistent among all injected embryos at $48 \mathrm{hpf}$, the time point when we performed all analyses.

\section{DJ-I expression is induced in zebrafish under oxidative stress and retains cell survival}

Both control and DJ-1 MO injected embryos shared an almost identical morphology (Fig. 2A), and no dramatic change in phenotype was observed in DJ-1 MO injected embryos (Fig. 2B). Since a loss of DJ-1 in humans leads to PD that is characterized in part by a gradual loss of tyrosine hydroxylase (TH)-positive dopaminergic neurons, we examined the expression of TH in zebrafish embryos by in situ hybridization. We failed to observe any alteration in TH staining in the DJ-1 KD embryos compared with control MO injected embryos at $48 \mathrm{hpf}$ (Fig. 2C, D) suggest-

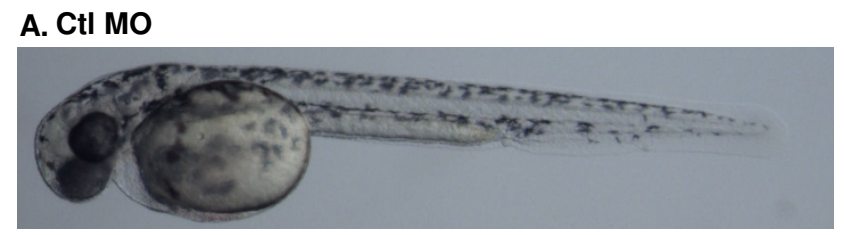

\section{B. DJ1 MO}

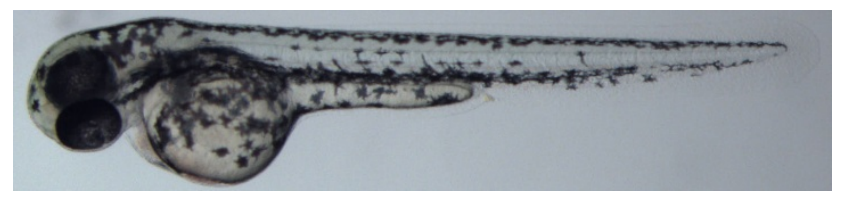

\section{CtI MO}

\section{DJ-1 MO}
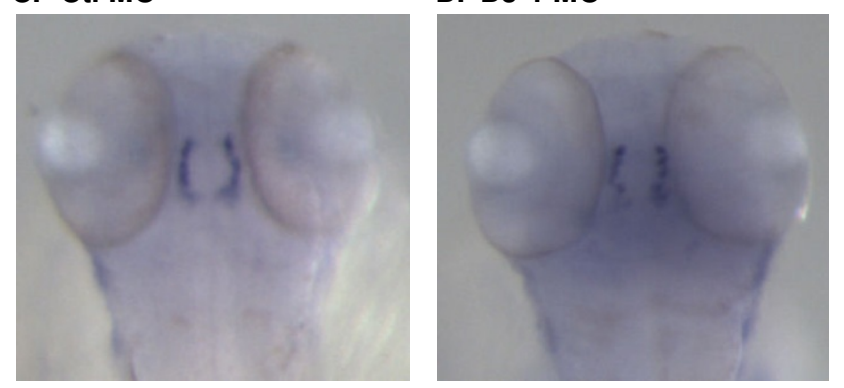

Figure 2

DJ-I expression is not essential for proper zebrafish development. A, B. Embryos were injected with control or $\mathrm{DJ}-\mathrm{I} M O$ at the one cell stage, and images were acquired at $48 \mathrm{hpf}$. DJ-I KD fish did not differ in morphologic phenotype compared to control MO injected zebrafish. C, D. Embryos injected with control or DJ-I MO were fixed at $48 \mathrm{hpf}$, followed by in situ hybridization using a probe against $\mathrm{TH}$. $\mathrm{TH}$ staining of control or DJ-I MO injected embryos was almost identical.

ing that formation of dopaminergic like neurons in zebrafish was not affected by a loss of DJ-1 protein.

We further examined islet-1 positive primary neurons that play an important role during zebrafish neural development. After control and MO injected embryos were fixed at $48 \mathrm{hpf}$, we carried out immunostaining using an antibody against islet- 1 , as we have previously reported [50]. We also treated control embryos with $0.03 \% \mathrm{H}_{2} \mathrm{O}_{2}$ to induce an environment of oxidative stress. We found that control MO injected embryos showed well defined islet-1 positive neurons along the spinal cord (Fig. $3 \mathrm{~A}$ ). In the presence of $\mathrm{H}_{2} \mathrm{O}_{2}$, staining in control DJ-1 injected embryos was slightly reduced, but islet- 1 positive cells could still be identified (Fig. 3B). Similarly, DJ-1 KD embryos showed weak staining of islet- 1 positive cells (Fig. 3C).

When the same set of embryos was examined for the presence of apoptotic cells by TUNEL staining, control MO 
A. CtI MO

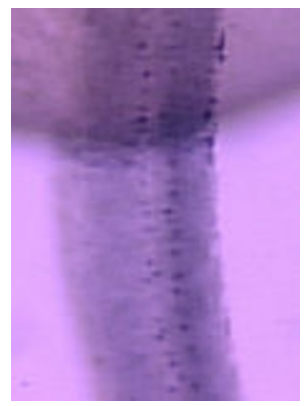

B. Ctl $\mathrm{MO}+\mathrm{H}_{2} \mathrm{O}_{2}$

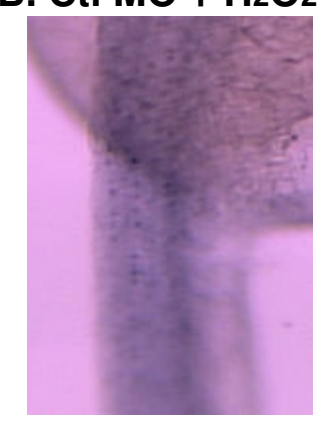

C. DJ-1 MO

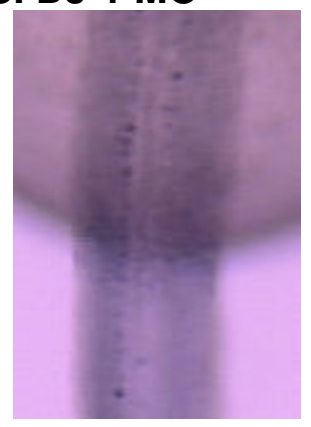

D. CtI MO

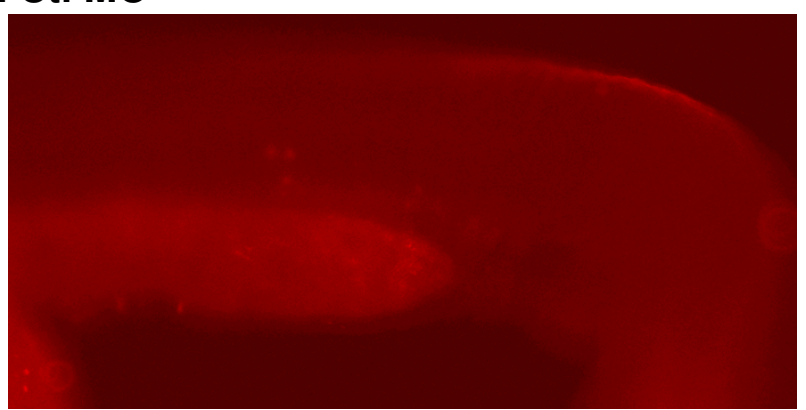

E. Ctl $\mathrm{MO}+\mathrm{H}_{2} \mathrm{O}_{2}$

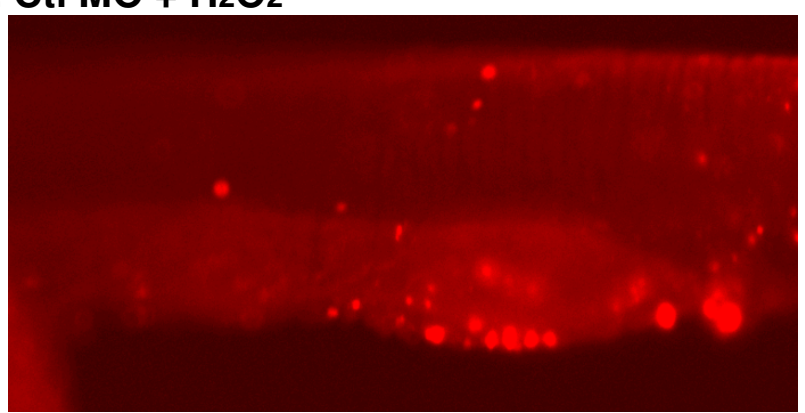

F. DJ-1 MO

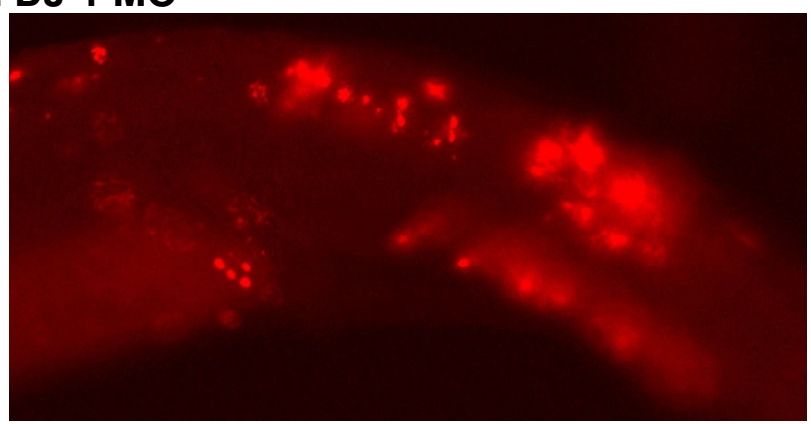

G. $\mathrm{H}_{2} \mathrm{O}_{2}$

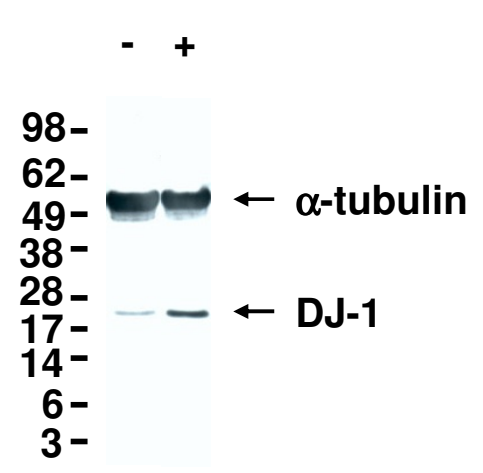

Figure 3

DJ-I expression is induced in zebrafish treated with $\mathrm{H}_{2} \mathrm{O}_{2}$ and knockdown of DJ-I increases the number of apoptotic cells. A. Control MO injected embryos showed normal distribution of islet-I positive neurons along the spinal cord, as illustrated by the dorsal view of the spinal cord, anterior to the top of the image. B. Control MO injected embryos treated with $\mathrm{H}_{2} \mathrm{O}_{2}$ showed a slight reduction in islet-I staining. C. DJ-I MO injected embryos displayed even weaker islet-I staining. D-F. Control MO (D, E) or DJ-I MO (F) was injected into embryos at one cell stage; after $24 \mathrm{hr}$, control MO injected embryos were treated with $0.03 \% \mathrm{H}_{2} \mathrm{O}_{2}$ for $30 \mathrm{~min}$. Compared to control $\mathrm{MO}$ injected embryos (D), there was an increase of TUNEL positive cells in the tails of $\mathrm{H}_{2} \mathrm{O}_{2}$ treated embryos (E) and DJ-I MO injected embryos (F). The lateral view of the trunk region of zebrafish was illustrated with anterior to the left of the image. The number of apoptotic cells in the tails of $\mathrm{H}_{2} \mathrm{O}_{2}$ treated embryos (E) and DJ-I KD embryos $(F)$ is higher than that in control MO injected embryos (D). G. Adult zebrafish were treated with $0.03 \% \mathrm{H}_{2} \mathrm{O}_{2}$ for 30 min before brains were harvested and lysed for Western blot. $\alpha$-Tubulin (an internal sample loading control) was detected over the upper portion of the blot, and the bottom portion of the blot was detected with antibody DJ-I-N. While the levels of $\alpha$-tubulin were not changed in the presence of $\mathrm{H}_{2} \mathrm{O}_{2}$, the levels of DJ-I were increased.

injected embryos yielded fewer apoptotic cells (Fig. 3D), but the treatment of these embryos with $\mathrm{H}_{2} \mathrm{O}_{2}$ increased the number of apoptotic cells (Fig. 3E). A similar result was obtained in DJ-1 KD embryos, which showed increased TUNEL staining, i.e., an increased number of apoptotic cells (Fig. 3F).
Since we found that DJ-1 was expressed throughout development and into adulthood (Fig. 1B), we explored the regulation of DJ-1 expression in adult fish under a stressful condition, such as oxidative stress. We created an environment of oxidative stress by exposing adult fish to $0.03 \% \mathrm{H}_{2} \mathrm{O}_{2}$ in their tank water. We found increased lev- 
els of DJ-1, by western blot, in the brains of fish exposed to $0.03 \% \mathrm{H}_{2} \mathrm{O}_{2}$ compared with fish from the control environment (Fig. 3G).

$D J-I$ is expressed in pyramidal neurons in AD hippocampus Because oxidative stress is one of the major contributors to $\mathrm{AD}[38,39]$, we examined whether up-regulation of DJ-1 occurred in human brains undergoing a neurodegenerative process. We analyzed brain tissue from individuals with well-defined cases of AD. DJ-1 was examined in briefly fixed hippocampal sections from postmortem AD brains using our newly generated, affinity purified DJ-1-N antibody (Fig. 4A) ( $\mathrm{n}=10$, age range: $77-92$, Braak Stage: III-VI) [51] and non-demented control cases $(n=9$, age range; 52-91). The intensity of the staining was variable among the $\mathrm{AD}$ cases, although it did not seem to correlate with the severity of the disease based on Braak staging [51] (data not shown). There was an absence of staining when the DJ-1-N antibody was preabsorbed with synthetic DJ-1 peptide prior to incubation on sections (Fig. 4B) and
A

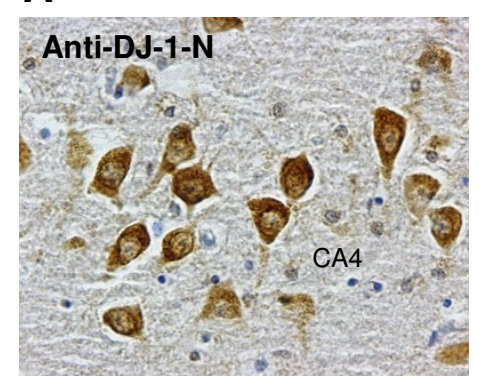

C

E.
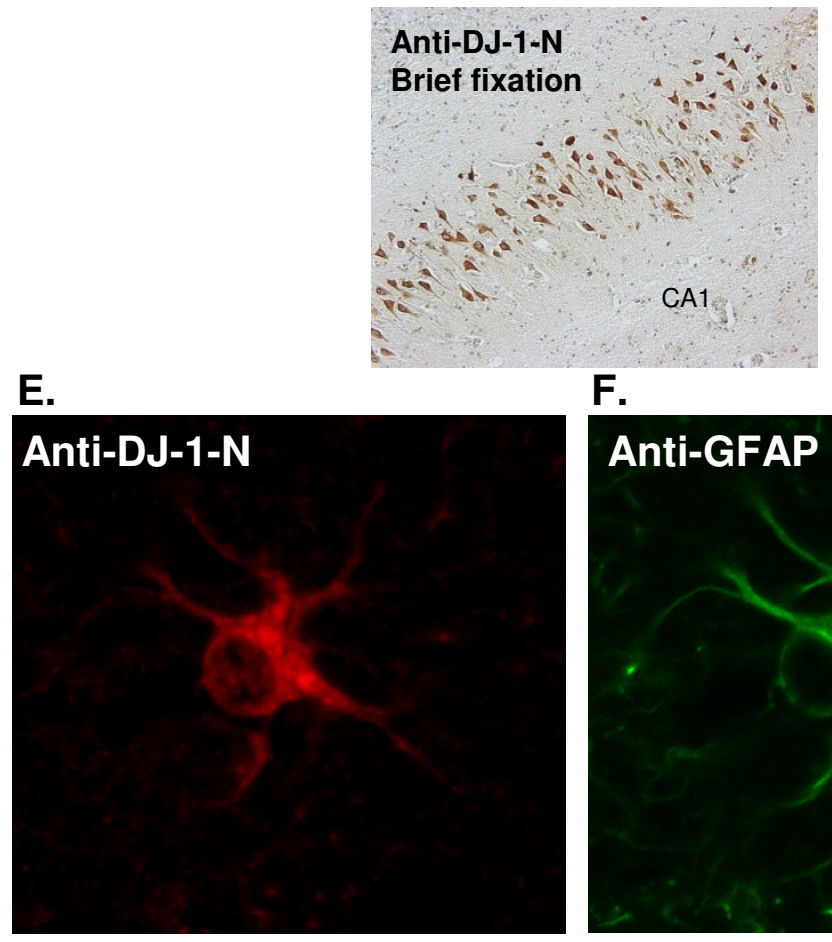

F.
B

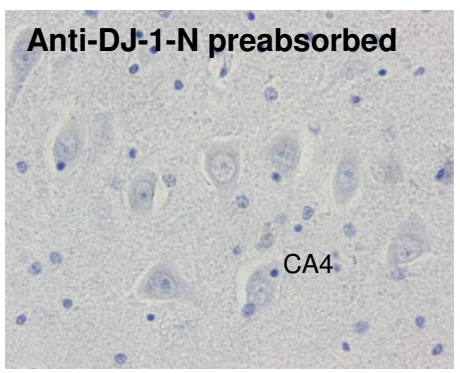

D

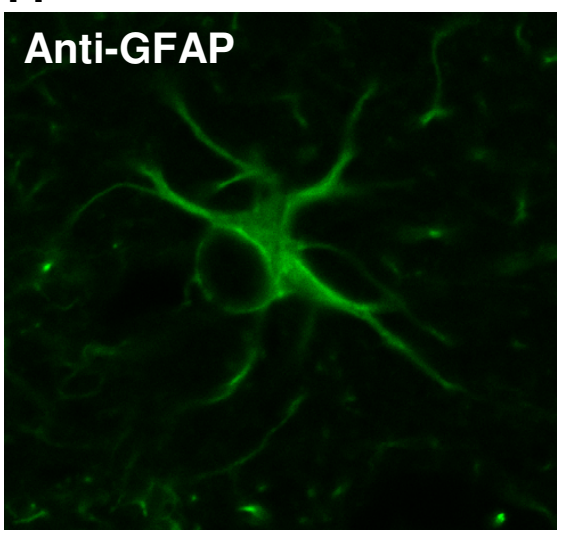

G.

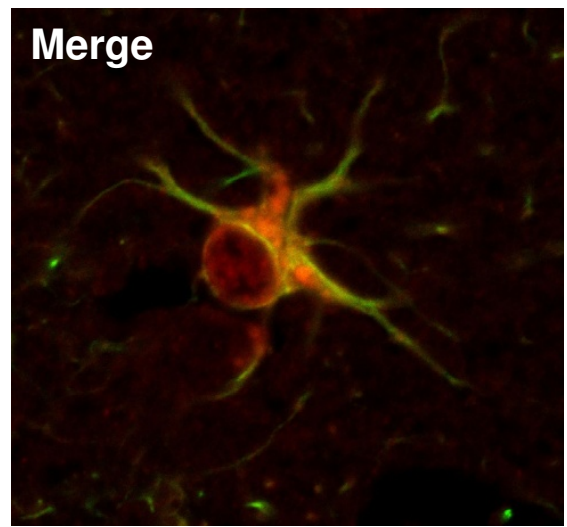

\section{Figure 4}

DJ-I is detected in neurons from briefly fixed post mortem AD brains. A. Affinity purified antibody DJ-I-N detected neurons in brain section from AD cases. Staining was observed in pyramidal neurons of CAI, CA2 and CA3 subregions. B. Absence of staining in AD brain with anti-DJ-I-N preabsorbed with DJ-I peptide, compared to an adjacent section immunostained with anti-DJ-N (A). C. DJ-I immunoreactivity in a briefly fixed ( 2 hours) section was easily detected. D. DJ-I-N failed to stain a routinely fixed ( $\sim 2-4$ weeks) section from the same AD case. E-G, Co-Staining of DJ-I and GFAP in astrocytes of human brain sections. A routinely fixed section from control brain was stained with antibody DJ-I-N (E) and GFAP (F). Double immunofluorescent overlay indicates the location of $D J-I$ in astrocytes (G). Magnification: $A, B=40 \times ; C, D=20 \times$. 
when primary antibody was omitted (data not shown). Brief fixation ( $<2$ hours) (Fig. 4C), as opposed to longterm fixation (2-4 weeks) (Fig. 4D) was critical for optimal neuronal DJ-1 immunostaining. We also explored DJ1 expression in astrocytes. Double immunofluorescence labeling with anti-DJ-1-N (Fig. 4E) and anti-GFAP antibody (Fig. 4F) further confirmed the presence of DJ-1 in astrocytes (Fig. 4G).

Similar to DJ-1-N (Fig. 5A), three commercially available DJ-1 antibodies, E2.19 (Fig. 5C), KAM-SA100 (Fig. 5E), and Park7 (Fig. 5G) were able to detect DJ-1 in neurons in adjacent sections of the same $\mathrm{AD}$ patient, but the staining was much weaker. Anti-DJ-1-N (Fig. 5B), E2.19 (Fig. 5D), and KAM-SA100 (Fig. 5F) detected astocyte DJ-1 in briefly, as well as, routinely fixed sections, with Park 7 showing much less staining (Fig. 5H).

Control brains $(n=9)$ also showed DJ-1 immunoreactivity in scattered astrocytes (data not shown), but they showed weak or no DJ-1 staining in pyramidal neurons of the CA1, CA2, CA3 sub-regions and the hilus of the dentate gyrus (CA4) (Fig. 6A, B), except for one case (C2, Table 1). In AD brains, 6 out of 10 cases showed moderate to abundant staining of DJ-1 (Table 1). DJ-1 immunoreactivity was observed in pyramidal neurons (cytoplasm and neuronal processes) of CA1-4 regions (Fig. 6C, D). Examination of other cortical areas revealed DJ-1 immunopositive neurons in the enthorinal cortex, frontal lobe and occipital lobe (data not shown). The staining for DJ1 in brain sections from control and AD subjects was summarized in Table 1.

To search for any mechanistic cause for DJ-1 expression in $\mathrm{AD}$ brains, we examined the effect of $\mathrm{A} \beta$ on the regulation of DJ-1 expression. We have used two cell lines, $\mathrm{CHO}$ that expresses endogenous levels of APP, and $\mathrm{CHO}+\mathrm{APP}$ that expresses high levels of APP and generates a large amount of $A \beta$. When we measured the conditioned media from $\mathrm{CHO}$ and $\mathrm{CHO}+\mathrm{APP}$ cells, we found elevated levels of $\mathrm{A} \beta 40$ (Fig. 7A, before treatment) and $\mathrm{A} \beta 42$ (Fig. 7B, before treatment) in the media from $\mathrm{CHO}+\mathrm{APP}$ cells, compared to undetectable level of $A \beta$ in the media from CHO cells (Fig. 7A and 7B). We applied conditioned media to PC-12 cells for 24 hrs, and collected media and cells for the quantification of $A \beta$ and DJ- 1 . We found that the conditioned media continued to carry high levels of $\mathrm{A} \beta 40$ (Fig. 7A, after treatment) and $\mathrm{A} \beta 42$ (Fig. 7B, after treatment). Despite of the $A \beta$ exposure, the expression levels of DJ-1 in PC-12 cells maintained at similar levels (Fig. 7C). Therefore, endogenous DJ-1 expression in PC-12 cells did not change in the presence of extracellular $A \beta$.

\section{Discussion and conclusion}

It is known that oxidative stress and mitochondrial dysfunction contribute to the pathogenesis of $\mathrm{AD}$ and $\mathrm{PD}$. In $\mathrm{AD}, \mathrm{A} \beta$ may directly interact with mitochondria and lead to increased free radical production; in PD, DJ-1, parkin and PINK1 are all linked to oxidative stress and/or mitochondrial dysfunction \{Reviewed by $[52,53]\}$. In this study, we aimed to examine the relationship between DJ1 and oxidative stress in zebrafish and also explore the spatial association of DJ-1 to neurons in AD brains.

Consistent with earlier studies in DJ-1 KO mice [22-24], $\mathrm{KD}$ of DJ-1 in zebrafish embryos did not result in a change in TH expression $\{[27]$ and this study $\}$. Previous studies have focused on pharmacologic treatment of zebrafish to reduce the number of DA-like neurons in zebrafish, e.g., MPTP, rotenone, and paraquat [34]. Extensive loss of DA neurons found in human forebrains and midbrains are responsible for most symptoms that are observed in PD patients, as these DA neurons control postural reflexes and initiation of movement. Genetic ablation of DA neurons becomes possible in light of a successful creation of a transgenic zebrafish expressing GFP in DA-like monoaminergic neurons [37]. Results from our study suggest that knocking down DJ-1 alone is not sufficient to reduce TH-positive DA-like neurons in zebrafish. Instead, a combination of DJ-1 knockdown/knockout and neuronal insult is needed to model pathogenesis in brains of zebrafish. Comparing embryos injected with control $\mathrm{MO}$ and those injected with DJ-1 MO, a slightly reduced staining of islet- 1 positive neurons was observed in the latter group. Islet-1 expresses at the earliest stage of neural differentiation. It is highly conserved during evolution, and is expressed in the many functional classes of primary neurons at $24 \mathrm{hpf}$ [54-58]. The decrease in the number of islet-1 positive cells in the DJ-1 KD embryos was not high enough to cause abnormal neuronal development, with the DJ-1 MO injected embryos showing hardly any morphologic difference compared to the control MO injected embryos $\{[27]$ and this study $\}$.

We found that DJ-1 KD embryos have an increased number of apoptotic cells, consistent with an earlier report showing a p53 dependent apoptosis in DJ-1 KD zebrafish embryos [27]. In cultured cells, DJ-1 directly interacts with p53 to inhibit its transcriptional activity [16]. Since knocking down DJ-1 increases BAX protein levels and caspase- 3 activation in cultured cells, knocking down DJ-1 in zebrafish likely undergoes similar pathways that lead to enhanced apoptosis. Another pathway that may be activated in the absence of DJ-1 is the MEKK1SEK1-JNK1 signaling pathway, as DJ-1 has been shown to directly target MEKK1 and inhibit MEKK1 kinase activity [19]. Knocking down DJ-1 may trigger this pathway thereby increasing the number of apoptotic cells. 

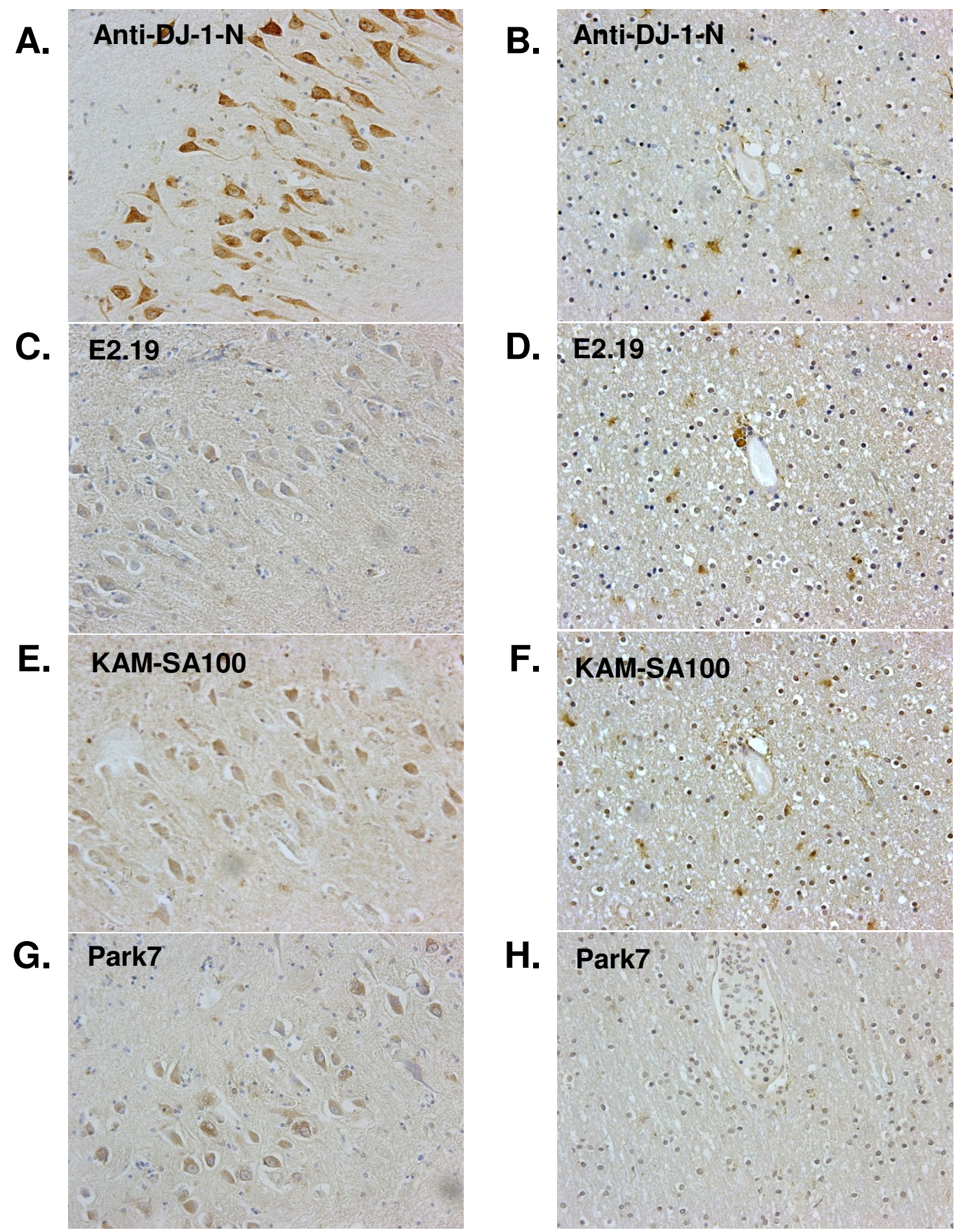

\section{Figure 5}

DJ-I is detected in both neurons and astrocytes by multiple antibodies. Antibody DJ-I-N (A) has stronger neuronal staining than three commercially available DJ-I antibodies, E2.19 (C), KAM-SAI00 (E), and Park7 (G) that also detected DJ-I in neurons in all adjacent briefly fixed sections of the same AD patient. DJ-I-N (B), E2.19 (D), and KAM-SAI00 (F) detected immunoreactivity in astrocytes in routinely fixed sections, and Park7 showed a much weaker staining of astrocytes $(\mathrm{H})$. Magnification: $20 x$. 


\section{A}

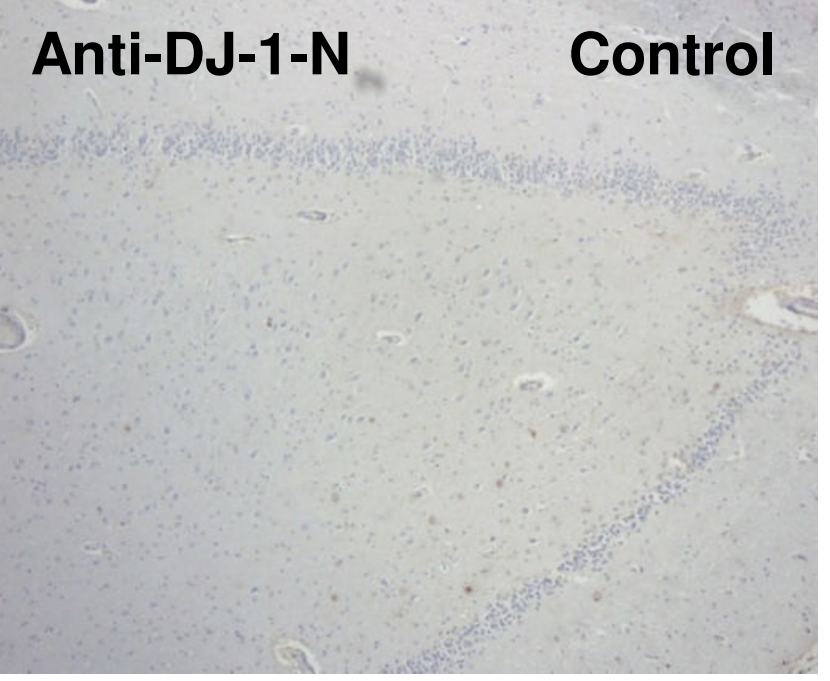

C

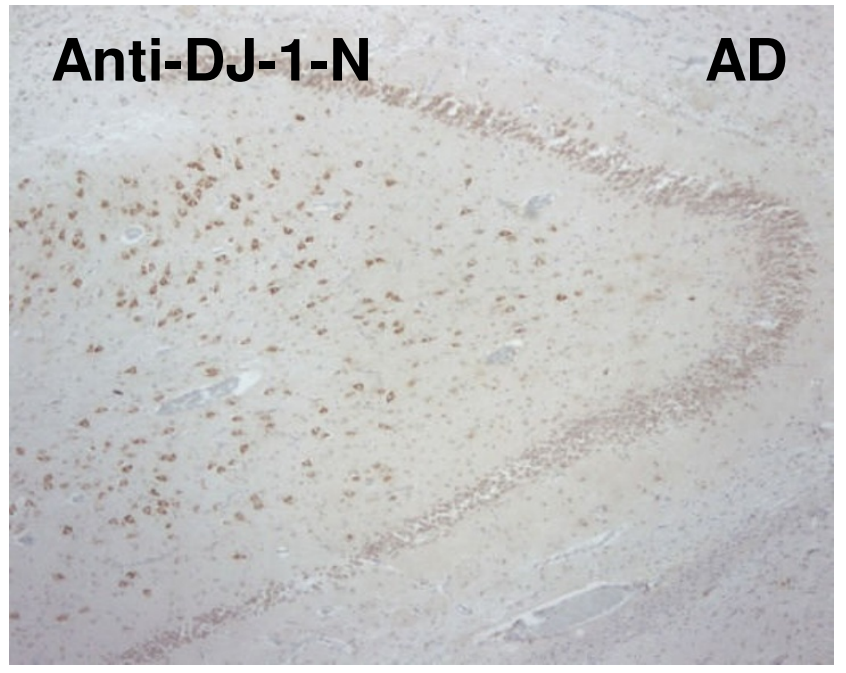

B

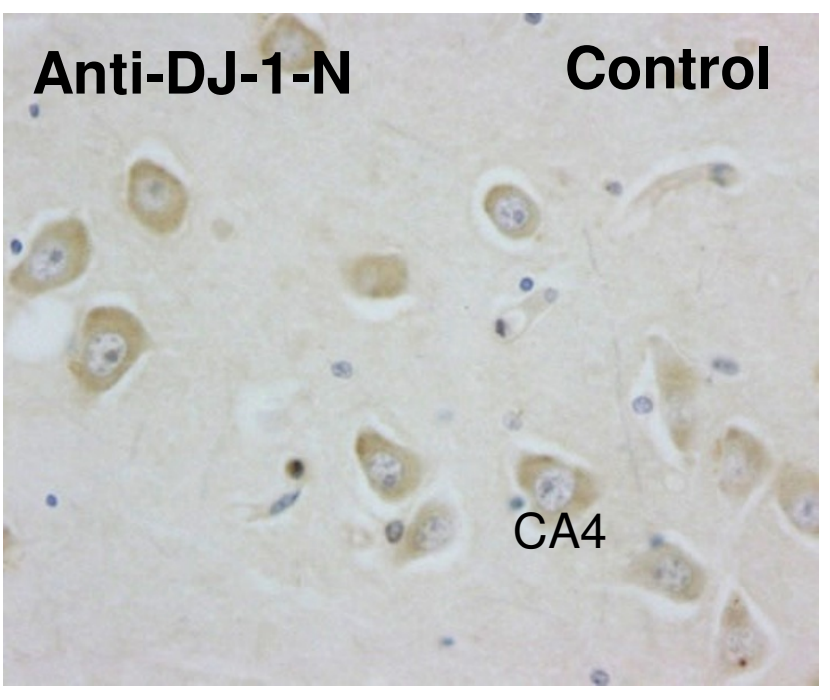

D

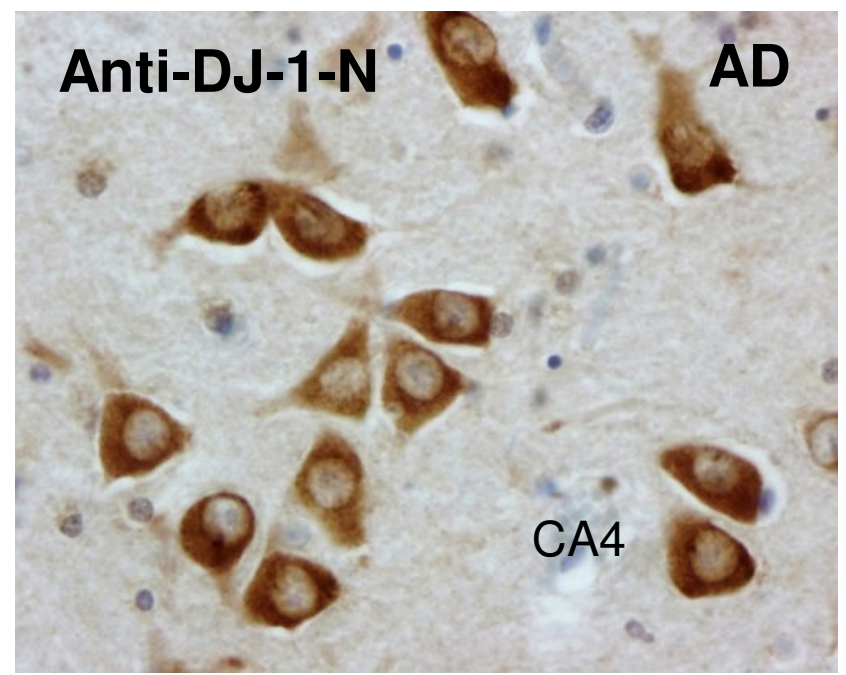

\section{Figure 6}

Enhanced immunostaining of DJ-I in AD but not control brains. $A$, B. control brains $(n=9)$ showed weak or no DJ-I staining in pyramidal neurons of the CAI, CA2, CA3 sub-regions and the hilus of the dentate gyrus (CA4). C, D. AD brains (n $=6 / 10$ ) showed DJ-I immunoreactivity in pyramidal neurons (cytoplasm and neuronal processes) of CAI-4 regions. Magnification: $A, C=4 \times ; B, D=40 x$.

Recent studies have shown that DJ-1 expression is up-regulated in cultured cells in an environment that promotes the formation of intracellular reactive oxygen species $[13,14]$. We have studied the effects of high levels of $\mathrm{H}_{2} \mathrm{O}_{2}$ on DJ-1 expression in the brains of adult zebrafish in vivo. For the first time, we found an increase in DJ-1 protein in brains of adult fish subjected to a stressful environment such as oxidative stress. While it is difficult to discern whether the increase in DJ-1 was derived from neuronal or glial sources, we predict that it was a global response from exposure to $\mathrm{H}_{2} \mathrm{O}_{2}$ in the environment.

To further address this relationship, we utilized brain sections from post mortem $\mathrm{AD}$ and control subjects. We found that the avidity of different antibodies and the methods for preserving brain tissues were critical for revealing DJ-1 immunostaining. Whereas antibodies raised against the C-terminus of DJ-1 (Park7) [8,9] or full- 
Table I: Summary of DJ-I Staining in Brains from Control and AD Subjects

\begin{tabular}{|c|c|c|c|c|}
\hline Subject & $\operatorname{sex}$ & age & Diagnosis & DJ-I \\
\hline $\mathrm{Cl}$ & $\mathrm{F}$ & 76 & control & - \\
\hline$C 2$ & $M$ & 52 & control & ++ \\
\hline C3 & $M$ & 53 & control & - \\
\hline C4 & $\mathrm{F}$ & 72 & control & - \\
\hline C5 & $M$ & 70 & control & - \\
\hline C6 & $\mathrm{F}$ & 60 & control & - \\
\hline C7 & $M$ & 64 & control & - \\
\hline $\mathrm{C} 8$ & $M$ & 73 & control & - \\
\hline C9 & $M$ & 91 & control & - \\
\hline $\mathrm{Al}$ & $M$ & 77 & $A D$ & - \\
\hline $\mathrm{A} 2$ & $\mathrm{~F}$ & 91 & $A D$ & - \\
\hline $\mathrm{A} 3$ & $\mathrm{~F}$ & 81 & $A D$ & ++ \\
\hline A4 & $\mathrm{F}$ & 88 & $A D$ & + \\
\hline A5 & $M$ & 78 & $A D$ & ++ \\
\hline A6 & $M$ & 78 & $A D$ & ++++ \\
\hline A7 & $\mathrm{F}$ & 92 & $A D$ & ++ \\
\hline A8 & $\mathrm{F}$ & 84 & $A D$ & ++ \\
\hline A9 & $\mathrm{F}$ & 86 & $A D$ & - \\
\hline AlO & $\mathrm{F}$ & 80 & $A D$ & ++ \\
\hline
\end{tabular}

Note: -, none; +, low; ++, moderate; +++, high; ++++, abundant.

length DJ-1 (KAM-SA100 and E2.19) [7,8] predominantly detect reactive astrocytes with less robust neuronal staining, our N-terminal DJ-1-N antibody efficiently stained both astrocytes and pyramidal neurons. The specificity of our affinity purified DJ-1-N was demonstrated by our comparison of tissue lysates from wild type and DJ-1 KO mouse brains. Furthermore, DJ-1-N only detected a single band on our Western blot of human brain lysates. Therefore, immunostaining of human brain sections with DJ-1$\mathrm{N}$ was highly specific, and the robust signals from $\mathrm{AD}$ brain sections represent high levels of DJ-1 protein in these neurons.
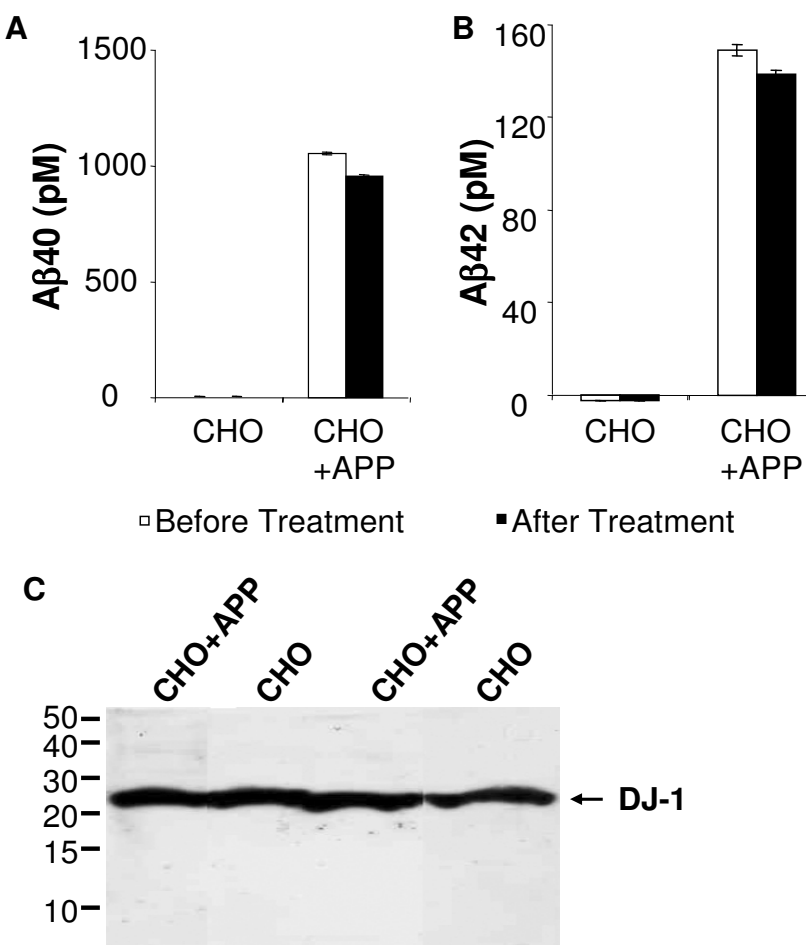

Figure 7

Lack of changes in $\mathrm{DJ}-\mathrm{I}$ expression in the presenceof A $\beta$. Conditioned media from $\mathrm{CHO}$ and $\mathrm{CHO}+\mathrm{APP}$ cells were collected for the measurement of $A \beta$ levels and treatment of PC- 12 cells. A. High levels of $A \beta 40$ were found in the media from CHO+APP cells before (white bar) and after (black bar) the treatment of PC- 12 cells (the standard error of means was illustrated). B. High levels of $A \beta 42$ were found in the media from $\mathrm{CHO}+\mathrm{APP}$ cells before (white) and after (black) the treatment of $\mathrm{PC}-12$ cells, compared to undetectable amount of $A \beta$ in the media from $\mathrm{CHO}$ cells. $\mathrm{C}$. Conditioned media from $\mathrm{CHO}$ or $\mathrm{CHO}+\mathrm{APP}$ cells were applied to PC- 12 cells for $24 \mathrm{hr}$, and cells were collected for the quantification of $D J-I$ by Western blot using antibody DJ-I-N. Cells from two independent experiments were collected, and the expression levels of DJ-I in both sets of PC- 12 cells maintained at similar levels.

Our comparison staining with DJ-1-N and other DJ-1 antibodies (E2.19, KAM-SA100 and Park7) reveals an important finding on the potential binding region of DJ1 when it dimerizes. Earlier reports, including ours, have demonstrated that DJ-1 dimerizes and forms a high molecular weight complex in cultured cells and human brains [21,59]. It seems that the mid- and C-terminal regions of DJ-1 could be involved in dimerization and are no longer accessible by antibodies that recognize these regions. However, the N-terminal region of DJ-1 may still be exposed and not involved in binding in the dimer or high molecular weight complex. DJ-1-N may therefore efficiently detect the exposed antigen in brain sections. 
This finding is identical to what we have found in $\mathrm{A} \beta \mathrm{dim}$ ers, where N-terminal antibodies more effectively capture dimeric $A \beta$ compared to antibodies recognizing mid- and $\mathrm{C}$-terminal regions of $\mathrm{A} \beta$ [46]. Whether the $\mathrm{N}$-terminus of DJ-1 is somehow altered during long term fixation is not clear, as strong staining of DJ-1 only in briefly fixed brain sections suggests that the method of preserving post mortem brains plays an important role.

The intriguing finding of positive staining of DJ-1 in AD brains but not control brains has important implications for both $\mathrm{PD}$ and $\mathrm{AD}$ pathogenesis. In brains of $\mathrm{AD}$ patients, the neuritic plaque composed of $A \beta$ is one of the major characteristics of AD pathology. A lack of change in DJ-1 expression in cultured cells exposed to high levels of $A \beta$ suggests that $A \beta$ has no direct effect on steady state levels of DJ-1. During the neurodegenerative process, accumulation of reactive oxygen species renders neurons, such as pyramidal neurons around hippocampal area, extremely vulnerable, and gradual neuronal loss is inevitable when the brain is exposed to insults. The fact that DJ1 itself is subjected to cysteine and methionine oxidation [11] as well as the increment of DJ-1 expression in zebrafish under oxidative stress provides important clues to our findings in human brains. It seems that the damaged DJ-1 failed to prevent oxidative stress-induced gradual neuronal death when neurons in $\mathrm{AD}$ brains were exposed to an environment with high levels of reactive oxygen species. In certain areas of the brain in $\mathrm{AD}$ patients, levels of functional DJ-1 may be reduced, leading to neuronal death. Under these conditions, human brain may respond with an increased expression of DJ-1, like zebrafish exposed to $\mathrm{H}_{2} \mathrm{O}_{2}$. Therefore, the similarity of increased DJ-1 staining in $\mathrm{H}_{2} \mathrm{O}_{2}$ treated zebrafish and AD brains suggest that a common pathway might be elicited under damaging conditions. As previously reported, DJ-1 is needed to avoid oxidative stress-induced cell death in cultured neuroblastomas, dopaminergic cells and primary neuronal cells [60]. Therefore, our results suggest that surviving neurons found in $\mathrm{AD}$ hippocampus expressed high levels of DJ-1 in response to a damaging environment, whereas in control brains few exogenous factors induced the expression of DJ-1.

Furthermore, DJ-1 is a non-traditional peroxiredoxin-like peroxidase [23], and enhanced levels of DJ-1 in pyramidal neurons in AD brain may simply represent a response to an accumulation of reactive oxygen species in the mitochondria. This is supported by the finding that mitochondria isolated from DJ-1 KO mice have increased levels of $\mathrm{H}_{2} \mathrm{O}_{2}[23]$.

Future studies are necessary to characterize the role of DJ1 in PD and AD pathogenesis such as whether the DJ-1 protein we found in pyramidal neurons in AD hippocam- pus is an acidic isoform [10], basic isoform [11], or both. A specific isoform of DJ-1 may lose its protective role in neuronal survival while oxidation of cysteine/methionine in DJ-1 may lead to a detrimental effect on neurons. The novel finding of an increased DJ-1 expression in zebrafish treated with $\mathrm{H}_{2} \mathrm{O}_{2}$ illustrates a new plate form that allows us to examine the role of DJ-1 involved in response to oxidative stress. Investigation of the function/dysfunction of DJ-1 in a whole vertebrate animal exposed to a stressful environment has a direct physiological relevance to human diseases. Therefore, exploring mechanisms of DJ1 associated with $\mathrm{PD}$ and $\mathrm{AD}$ pathogenesis will provide insight into common pathways involved in both neurodegenerative diseases. Any newly identified pathways will offer novel drug targets and exciting opportunities for therapeutic intervention.

\section{Abbreviations}

AD: Alzheimer's disease; $\mathrm{A} \beta$ : amyloid $\beta$-protein; $\mathrm{DA}$ : dopaminergic; hpf: hours post fertilization; KD: knock down; KO: knock out; MO: morpholino; МРТP: 1 methyl-4-phenyl-1,2,3,6-tetrahydropyridine; PD: Parkinson's disease; TH: tyrosine hydroxylase.

\section{Competing interests}

The authors declare that they have no competing interests.

\section{Authors' contributions}

SB and JS carried out the biochemical and immunohistochemical analyses, HL carried out zebrafish experiments, TY carried out cell culture experiments, MS, JS, MGS, CAL, and QL participated in the design of the study, SB and WX conceived of the study and draft the manuscript. All authors read and approved the final manuscript.

\section{Acknowledgements}

We would like to thank Dr. J. Chan for providing human brain tissue, neuropathogical expertise and Dr. Matthew LaVoie for helpful discussion, Dr. Y. Hod for providing E2.19 antibody, Dr. S Guo for providing CDNA construct for TH probe. This study was supported by the Foundation SingerPolignac (SB), National Institute of Aging AG 026630 (QL), and the Harvard Center for Neurodegeneration and Repair (WX).

\section{References}

I. Polymeropoulos MH, Lavedan C, Leroy E, Ide SE, Dehejia A, Dutra A, Pike B, Root H, Rubenstein J, Boyer R, et al.: Mutation In the Alpha-Synuclein Gene Identified In Families With Parkinsons Disease. Science 1997, 276(532I):2045-2047.

2. Paisan-Ruiz C, Jain S, Evans EW, Gilks WP, Simon J, Brug M van der, Lopez de Munain A, Aparicio S, Gil AM, Khan N, et al:: Cloning of the gene containing mutations that cause PARK8-linked Parkinson's disease. Neuron 2004, 44(4):595-600.

3. Zimprich A, Biskup S, Leitner P, Lichtner P, Farrer M, Lincoln S, Kachergus J, Hulihan M, Uitti RJ, Calne DB, et al.: Mutations in LRRK2 cause autosomal-dominant parkinsonism with pleomorphic pathology. Neuron 2004, 44(4):60I-607.

4. Bonifati V, Rizzu P, van Baren MJ, Schaap O, Breedveld GJ, Krieger E, Dekker MC, Squitieri F, Ibanez P, Joosse M, et al:: Mutations in the DJ-I gene associated with autosomal recessive early-onset parkinsonism. Science 2003, 299(5604):256-259. 
5. Valente EM, Abou-Sleiman PM, Caputo V, Muqit MM, Harvey K, Gispert S, Ali Z, Del Turco D, Bentivoglio AR, Healy DG, et al.: Hereditary early-onset Parkinson's disease caused by mutations in PINK I. Science 2004, 304(5674): I I 58- I I60. Epub 2004 Apr I I I 5

6. Kitada $T$, Asakawa $S$, Hattori $N$, Matsumine $H$, Yamamura $Y$, Minoshima S, Yokochi M, Mizuno Y, Shimizu N: Mutations in the parkin gene cause autosomal recessive juvenile parkinsonism. Nature 1998, 392:605-608.

7. Bandopadhyay R, Kingsbury AE, Cookson MR, Reid AR, Evans IM, Hope AD, Pittman AM, Lashley T, Canet-Aviles R, Miller DW, et al.: The expression of DJ-I (PARK7) in normal human CNS and idiopathic Parkinson's disease. Brain 2004, I 27(Pt 2):420-430. Epub 2003 Dec 2008

8. Neumann M, Muller V, Gorner K, Kretzschmar HA, Haass C, Kahle PJ: Pathological properties of the Parkinson's disease-associated protein DJ-I in alpha-synucleinopathies and tauopathies: relevance for multiple system atrophy and Pick's disease. Acta Neuropathol (Berl) 2004, I07(6):489-496. Epub 2004 Feb 2026

9. Rizzu P, Hinkle DA, Zhukareva V, Bonifati V, Severijnen LA, Martinez D, Ravid R, Kamphorst W, Eberwine JH, Lee VM, et al.: DJ-I colocalizes with tau inclusions: a link between parkinsonism and dementia. Ann Neurol 2004, 55(I): I I3-I I8.

10. Kumaran R, Kingsbury A, Coulter I, Lashley T, Williams D, de Silva R, Mann D, Revesz T, Lees A, Bandopadhyay R: DJ-I (PARK7) is associated with $3 R$ and $4 R$ tau neuronal and glial inclusions in neurodegenerative disorders. Neurobiol Dis 2007, 28(I): I $22-132$.

II. Choi J, Sullards MC, Olzmann JA, Rees HD, Weintraub ST, Bostwick $D E$, Gearing M, Levey Al, Chin LS, Li L: Oxidative damage of DJ-I is linked to sporadic Parkinson and Alzheimer diseases. J Biol Chem 2006, 28 I(16): 10816-10824.

12. Shang H, Lang D, Jean-Marc B, Kaelin-Lang A: Localization of DJ-I mRNA in the mouse brain. Neurosci Lett 2004, 367(3):273-277.

13. Ishimura A, Ishige K, Taira T, Shimba S, Ono S, Ariga H, Tezuka M, Ito $Y$ : Comparative study of hydrogen peroxide- and 4-hydroxy2-nonenal-induced cell death in HT22 cells. Neurochem Int 2008, 52(4-5):776-785.

14. Lev N, Ickowicz D, Melamed E, Offen D: Oxidative insults induce DJ-I upregulation and redistribution: implications for neuroprotection. Neurotoxicology 2008, 29(3):397-405.

15. Miyazaki S, Yanagida T, Nunome K, Ishikawa S, Inden M, Kitamura $Y$, Nakagawa S, Taira T, Hirota K, Niwa M, et al.: DJ-I-binding compounds prevent oxidative stress-induced cell death and movement defect in Parkinson's disease model rats. I Neurochem 2008, 105:24|8-2434.

16. Fan J, Ren H, Jia N, Fei E, Zhou T, Jiang P, Wu M, Wang G: DJ-I decreases Bax expression through repressing p53 transcriptional activity. J Biol Chem 2008, 283(7):4022-4030.

17. Fan J, Ren H, Fei E, Jia N, Ying Z, Jiang P, Wu M, Wang G: Sumoylation is critical for $D J-I$ to repress p53 transcriptional activity. FEBS Lett 2008, 582(7): II5I-I I 56.

18. Clements CM, McNally RS, Conti BJ, Mak TW, Ting JP: DJ-I, a cancer- and Parkinson's disease-associated protein, stabilizes the antioxidant transcriptional master regulator Nrf2. Proc Natl Acad Sci USA 2006, 103(4I): I509|-I5096.

19. Mo JS, Kim MY, Ann EJ, Hong JA, Park HS: DJ-I modulates UVinduced oxidative stress signaling through the suppression of MEKKI and cell death. Cell Death Differ 2008, 15(6):1030-104I.

20. Malgieri G, Eliezer D: Structural effects of Parkinson's disease linked DJ-I mutations. Protein Sci 2008, I 7(5):855-868.

21. Baulac S, LaVoie M, Strahle J, Schlossmacher M, Xia W: Dimerization of Parkinson disease-causing DJ-I and formation of high molecular weight complexes containing parkin in human brain. Mol Cell Neurosci 2004, 27:236-246.

22. Goldberg MS, Pisani A, Haburcak M, Vortherms TA, Kitada T, Costa C, Tong Y, Martella G, Tscherter A, Martins A, et al.: Nigrostriatal dopaminergic deficits and hypokinesia caused by inactivation of the familial Parkinsonism-linked gene DJ-I. Neuron 2005, 45(4):489-496.

23. Andres-Mateos E, Perier C, Zhang L, Blanchard-Fillion B, Greco TM, Thomas B, Ko HS, Sasaki M, Ischiropoulos H, Przedborski S, et al.: DJI gene deletion reveals that $\mathrm{DJ}-\mathrm{I}$ is an atypical peroxiredoxin-like peroxidase. Proc Natl Acad Sci USA 2007, 104(37): | 4807-| |48|2.
24. Kim RH, Smith PD, Aleyasin H, Hayley S, Mount MP, Pownall S, Wakeham A, You-Ten AJ, Kalia SK, Horne P, et al.: Hypersensitivity of DJ-I-deficient mice to I-methyl-4-phenyl-I,2,3,6-tetrahydropyrindine (MPTP) and oxidative stress. Proc Natl Acad Sci USA 2005, 102(14):5215-5220.

25. Yamaguchi $H$, Shen J: Absence of dopaminergic neuronal degeneration and oxidative damage in aged DJ-I-deficient mice. Mol Neurodegener 2007, 2(10): 10.

26. Bai Q, Mullett SJ, Garver JA, Hinkle DA, Burton EA: Zebrafish DJ-I is evolutionarily conserved and expressed in dopaminergic neurons. Brain Res 2006, I I I 3(I):33-44.

27. Bretaud S, Allen C, Ingham PW, Bandmann O: p53-dependent neuronal cell death in a DJ-I-deficient zebrafish model of Parkinson's disease. J Neurochem 2007, 100(6):1626-1635.

28. Lavara-Culebras E, Paricio N: Drosophila DJ-I mutants are sensitive to oxidative stress and show reduced lifespan and motor deficits. Gene 2007, 400: I-2.

29. Gerhard GS, Cheng KC: A call to fins! Zebrafish as a gerontological model. Aging Cell 2002, I (2): I04-III.

30. Goping G, Pollard HB, Adeyemo OM, Kuijpers GA: Effect of MPTP on dopaminergic neurons in the goldfish brain: a light and electron microscope study. Brain Res 1995, 687(I-2):35-52.

31. Pollard HB, Kuijpers GA, Adeyemo OM, Youdim MB, Goping G: The MPTP-induced parkinsonian syndrome in the goldfish is associated with major cell destruction in the forebrain and subtle changes in the optic tectum. Exp Neurol 1996, I42(I): I70-178.

32. Poli A, Guarnieri T, Facchinetti F, Villani L: Effect of I-methyl-4phenyl-I,2,3,6-tetrahydropyridine (MPTP) in goldfish brain. Brain Res 1990, 534(I-2):45-50.

33. Pollard HB, Dhariwal K, Adeyemo OM, Markey Cl, Caohuy H, Levine $M$, Markey S, Youdim MB: A parkinsonian syndrome induced in the goldfish by the neurotoxin MPTP. Faseb J 1992, 6(12):3108-3116.

34. Bretaud S, Lee S, Guo S: Sensitivity of zebrafish to environmental toxins implicated in Parkinson's disease. Neurotoxicol Teratol 2004, 26(6):857-864.

35. Puelles L, Verney C: Early neuromeric distribution of tyrosinehydroxylase-immunoreactive neurons in human embryos. $J$ Comp Neurol 1998, 394(3):283-308.

36. Reiner A, Northcutt RG: An immunohistochemical study of the telencephalon of the senegal bichir (Polypterus senegalus). J Comp Neurol 1992, 3 I 9(3):359-386.

37. Wen L, Wei W, Gu W, Huang P, Ren X, Zhang Z, Zhu Z, Lin S, Zhang $B$ : Visualization of monoaminergic neurons and neurotoxicity of MPTP in live transgenic zebrafish. Dev Biol 2008, 3 I 4(I):84-92.

38. Gu F, Zhu M, Shi J, Hu Y, Zhao Z: Enhanced oxidative stress is an early event during development of Alzheimer-like pathologies in presenilin conditional knock-out mice. Neurosci Lett 2008, 440(I):44-48.

39. Reddy $\mathrm{PH}$ : Amyloid precursor protein-mediated free radicals and oxidative damage: implications for the development and progression of Alzheimer's disease. J Neurochem 2006, 96(I): $1-13$.

40. Kimmel CB, Ballard WW, Kimmel SR, Ullmann B, Schilling TF: Stages of embryonic development of the zebrafish. Dev Dyn 1995, 203(3):253-310.

4I. Westerfield M: The Zebrafish Book Eugene, OR: University of Oregon Press; 1994.

42. Friso S, Girelli D, Trabetti E, Stranieri C, Olivieri O, Tinazzi E, Martinelli N, Faccini G, Pignatti PF, Corrocher R: Al 298C methylenetetrahydrofolate reductase mutation and coronary artery disease: relationships with C677T polymorphism and homocysteine/folate metabolism. Clin Exp Med 2002, 2(I):7-I2.

43. Thisse C, Thisse B, Schilling TF, Postlethwait JH: Structure of the zebrafish snaill gene and its expression in wild-type, spadetail, and no tail mutant embryos. Development 1993, I 19:1203-1215

44. Stoltzner SE, Grenfell TJ, Mori C, Wisniewski KE, Wisniewski TM, Selkoe DJ, Lemere CA: Temporal accrual of complement proteins in amyloid plaques in Down's syndrome with Alzheimer's disease. Am J Pathol 2000, 156(2):489-499.

45. Hod Y: Differential control of apoptosis by $D J-I$ in prostate benign and cancer cells. J Cell Biochem 2004, 92(6): | $22 \mid$ I-I 233. 
46. Xia W, Yang T, Shankar G, Smith I, Shen Y, Walsh D, Selkoe DJ: A Specific ELISA for Measuring Amyloid $\beta$-Protein Oligomer in Human Plasma and the Brains of Alzheimer Patients. Arch Neurol 2009, 66(2):190-199.

47. Nasevicius A, Ekker SC: Effective targeted gene 'knockdown' in zebrafish. Nat Genet 2000, 26(2):216-220.

48. Draper BW, Morcos PA, Kimmel CB: Inhibition of zebrafish fgf8 pre-mRNA splicing with morpholino oligos: a quantifiable method for gene knockdown. Genesis 200I, 30(3): I54-I56.

49. Ekker SC, Larson JD: Morphant technology in model developmental systems. Genesis 200I, 30(3):89-93.

50. Campbell WA, Yang HW, Zetterberg H, Baulac S, Sears JA, Liu T, Wong STC, Zhong TP, Xia W: Zebrafish lacking Alzheimer Presenilin Enhancer 2 (Pen-2) demonstrate excessive p53 dependent apoptosis and neuronal loss. J Neurochem 2006, 96:1423-1440.

51. Braak H, Braak E: Neuropathological stageing of Alzheimerrelated changes. Acta Neuropathol I991, 82(4):239-259.

52. Reddy PH, Beal MF: Amyloid beta, mitochondrial dysfunction and synaptic damage: implications for cognitive decline in aging and Alzheimer's disease. Trends Mol Med 2008, I 4(2):45-53.

53. Beal MF: Mitochondria, oxidative damage, and inflammation in Parkinson's disease. Ann N Y Acad Sci 2003, 99 I:|20-|3|.

54. Ericson J, Thor S, Edlund T, Jessell TM, Yamada T: Early stages of motor neuron differentiation revealed by expression of homeobox gene Islet-I. Science 1992, 256(5063): I555-I560.

55. Korzh $\mathrm{V}$, Edlund $\mathrm{T}$, Thor S: Zebrafish primary neurons initiate expression of the LIM homeodomain protein IsI-I at the end of gastrulation. Development 1993, I I 8(2):417-425.

56. Inoue A, Takahashi M, Hatta K, Hotta Y, Okamoto H: Developmental regulation of islet-I mRNA expression during neuronal differentiation in embryonic zebrafish. Dev Dyn 1994, 199(I): I-II.

57. Thor S, Thomas JB: The Drosophila islet gene governs axon pathfinding and neurotransmitter identity. Neuron 1997, I 8(3):397-409.

58. Jackman WR, Langeland JA, Kimmel CB: islet reveals segmentation in the Amphioxus hindbrain homolog. Dev Biol 2000, 220(I):16-26.

59. Olzmann JA, Brown K, Wilkinson KD, Rees HD, Huai Q, Ke H, Levey Al, Li L, Chin LS: Familial Parkinson's disease-associated LI 66P mutation disrupts DJ-I protein folding and function. J Biol Chem 2004, 279(9):8506-85I5.

60. Miyazaki K, Hasegawa M, Funahashi K, Umeda M: A metalloproteinase inhibitor domain in Alzheimer amyloid protein precursor. Nature 1993, 362:839-84I.

Publish with Bio Med Central and every scientist can read your work free of charge

"BioMed Central will be the most significant development for disseminating the results of biomedical research in our lifetime. "

Sir Paul Nurse, Cancer Research UK

Your research papers will be:

- available free of charge to the entire biomedical community

- peer reviewed and published immediately upon acceptance

- cited in PubMed and archived on PubMed Central

- yours - you keep the copyright
BioMedcentral 